\title{
A case of postganglionic cholinergic dysautonomia
}

\author{
HARUHIKO TAKAYAMA, YASUKO KAZAHAYA,* NAOKI KASHIHARA, \\ HIROO KURODA, SHOJI MIYAWAKI, ZENSUKE OTA, NORIO OGAWA $\dagger$ \\ From the Third Department of Internal Medicine, Department of Neuropsychiatry, ${ }^{*}$ and Institute for \\ Neurobiology, $\uparrow$ Okayama University Medical School, Okayama, Japan
}

SUMMARY A 24 year old female presented with signs and symptoms of postganglionic cholinergic autonomic dysfunction manifested by impaired lachrymation and salivation, mydriasis of the pupil, decreased gastrointestinal motility, atony of the bladder, and sweating and taste disturbance. Clinical and pharmacological studies confirmed that the abnormalities were restricted mainly to the postganglionic cholinergic autonomic systems. The titre of serum complement was low, antinuclear antibodies revealed a diffuse pattern, and anti SS-A antibody was positive, suggesting that this disorder was caused by an immune mechanism.

Since Young et al ${ }^{1}$ first described the acute onset of dysfunction of the peripheral autonomic nervous system without other neurological manifestations in 1969 , more than 20 cases have been reported. ${ }^{2-9}$ The disorder is characterised by symptoms suggesting disturbances in sympathetic and parasympathetic function, which come on abruptly and tend to resolve after a variable period of time. Although the pathogenesis of this disorder is still unknown, in some reports this disorder is considered to be an immune disorder. ${ }^{2} 310$

In this patient, we further examined for Sjögren's syndrome because of sicca syndrome, positive anti SS-A antibody, and low titre of serum complement, but clinical and pharmacological autonomic function studies indicated the diagosis of "postganglionic cholinergic dysautonomia". This may also be a case of an immune disorder.

\section{Case report}

A 24 year old female was admitted with a history of blurring of vision for near objects 3 months previously although distal visual acuity remained normal. At that time, she developed nausea, vomiting, fever of $38^{\circ} \mathrm{C}$ with dryness of the eyes and mouth, and difficulty in urination. Although the fever subsided after a few days, other symptoms continued. She was treated for a common cold, but she did not get well.

Address for reprint requests: $H$ Takayama, Third Department of Internal Medicine, Okayama University Medical School, 2-5-1 Shikatacho, Okayama 700, Japan.

Received 29 April 1986. Accepted 29 October 1986
Several weeks later, she visited an ophthalmologist and was found to have anisocoria, and sicca syndrome. The Schirmer test revealed $2 \mathrm{~mm}$ in the right eye and $1 \mathrm{~mm}$ in the left eye, and the Rose-bengal test was positive in both eyes. The ophthalmologist referred her to our department for further examination with the possible diagnosis of Sjögren's syndrome.

\section{Physical examination}

Her weight was $44.8 \mathrm{~kg}$, height $156.2 \mathrm{~cm}$, body temperature was $37^{\circ} \mathrm{C}$ and the blood pressure $114 / 56 \mathrm{~mm} \mathrm{Hg}$ in the supine position and $116 / 60 \mathrm{~mm} \mathrm{Hg}$ on standing.

On neurological examination, consciousness was clear and the right pupil was $5 \mathrm{~mm}$ in diameter, round and reaction to light was absent. The left pupil was $8 \mathrm{~mm}$ in diameter, round and reaction to light was absent. Accommodation was unclear and near visual acuity was decreased, but eye movement and visual field were normal and nystagmus was not found. The remainder of the cranial nerves were intact. Deep tendon reflexes were brisk and symmetrical bilaterally. No pathological reflexes could be elicited. Motor, sensory, cerebellar functions and gait were normal. Dryness of mouth made swallowing of solid food difficult but liquids were swallowed easily; taste disturbance was present. The tongue was dry but otherwise normal; there was no dysphonia. She complained of constipation, and bowel movement was diminished on auscultation.

\section{Laboratory findings}

On admission, although urinalysis showed cystitis, complete blood count, electrolytes, blood urea nitrogen, creatinine glucose and liver function tests were all normal. Serological tests for syphilis were negative. On immunological tests, although anti SS-B antibody, anti RNP antibody and anti Sm antibody were negative and titre of anti DNA antibody was normal $(5.6 \mathrm{U} / \mathrm{ml})$, titre of serum complement was low 
$(27.5 \mathrm{U} / \mathrm{ml})$, antinuclear antibodies revealed a diffuse pattern and anti SS-A antibody was positive. A labial salivary gland was biopsied, but light microscopic examination revealed no detectable abnormalities.

Radiographs of the chest and head CT scan were normal. Lumbar puncture yielded clear, colourless, acellular fluid under normal pressure $\left(140 \mathrm{~mm} \mathrm{H}_{2} \mathrm{O}\right)$, containing $53 \mathrm{mg} / \mathrm{dl}$ of glucose and $22 \mathrm{mg} / \mathrm{dl}$ of protein. Electroencephalogram (EEG) showed relatively slow waves in the occipital region for a 24 year old, but there was no laterality or focus. Motor nerve conduction velocities (MCVs) in the median and tibial nerves were normal, ranging from 46.5 to $53.7 \mathrm{~m} / \mathrm{s}$. Sensory

Table Special clinical investigation of autonomic function studies

\begin{tabular}{ll}
\hline Test & Response \\
\hline $\begin{array}{l}\text { Pupil: } \\
\text { Instillation of } 0 \cdot 1 \% \text { pilocarpine } \\
\text { Instillation of } 5 \% \text { cocaine } \\
\text { Instillation of } 5 \% \text { tyramine and } \\
1 \cdot 25 \% \text { epinephrine }\end{array}$ & $\begin{array}{l}\text { Marked constriction } \\
\text { Dilatation }\end{array}$ \\
$\begin{array}{l}\text { Piloerection: } \\
\text { Intradermal injection of } 10 \mathrm{mg}\end{array}$ & No response \\
$\begin{array}{l}\text { acetylcholine } \\
\text { Histamine test: } \\
\text { Intradermal injection of } 0 \cdot 1 \mathrm{mg} \\
\text { histamine }\end{array}$ & No response \\
$\begin{array}{l}\text { Sweating: } \\
\text { Heat }\end{array}$ & $\begin{array}{c}\text { Severe pain, Wheal, } \\
\text { Erythema }\end{array}$ \\
$\begin{array}{l}\text { Coefficient of variation of the R-R } \\
\text { interval in ECG } \\
\text { Vascular reflexes: } \\
\text { Change of posture } \\
\text { Cold pressor }\end{array}$ & $\begin{array}{c}\text { Decrease, Isolated } \\
\text { patches, Laterality }\end{array}$ \\
\hline & Normal \\
\hline
\end{tabular}

nerve conduction velocities (SCVs) in the median and sural nerves were also normal, ranging from 51.4 to $53.7 \mathrm{~m} / \mathrm{s}$.

\section{Studies of autonomic functions (table)}

Pupillary responses The instillation of $0 \cdot 1 \%$ pilocarpine into the conjunctival sac of the eye produced constriction of the pupils of both eyes (rt: $6.5 \mathrm{~mm} \rightarrow 4.5 \mathrm{~mm}$, lt: $7.0 \mathrm{~mm} \rightarrow 5.0 \mathrm{~mm}$ ). The instillation of $5 \%$ cocaine produced slight dilatation of the pupils in both eyes (rt: $6.5 \mathrm{~mm} \rightarrow 7.5 \mathrm{~mm}$, lt: $6.5 \mathrm{~mm} \rightarrow 7.0 \mathrm{~mm}$ ). The instillation of $5 \%$ tyramine and $1.23 \%$ epinephrine produced no changes. Piloerection There was no response following intradermal injection of $10 \mathrm{mg}$ acetylcholine.

Intradermal histamine Intradermal injection of $0.1 \mathrm{mg}$ histamine produced severe pain, and induced wheal and erythema which were smaller compared to control subjects. Sweating in response to body heating The normal response to heat was found to be decreased except on the foot and axilla. There were isolated patches on the chest and neck, and the sweat glands of the left face and neck did not function.

Coefficient of variation of the $R-R$ interval in $E C G$ $(C V) \mathrm{CV}$ values was normal, and $\mathrm{CV}$ values was decreased after intravenous injection of atropine $(30 \mu \mathrm{g} / \mathrm{kg})$ : a normal response.

Vascular reflexes Brisk change of posture from the supine to the standing position increased the heart rate from 72 to 76 per minute, and the blood pressure from $116 / 60$ to $114 / 56 \mathrm{~mm} \mathrm{Hg}$. Plasma norepinephrine level was 0.32 to $0.40 \mathrm{ng}$ per ml. Soaking her right forearm in a $4^{\circ} \mathrm{C}$ water bath (cold pressor) increased the heart rate from 84 to 90 per minute, and the blood pressure increased from 114/68 to $130 / 90 \mathrm{~mm} \mathrm{Hg}$.

Urodynamic tests (fig) There was extension of micturition time (47 s). Cystometry showed almost a normal pattern, but (a)

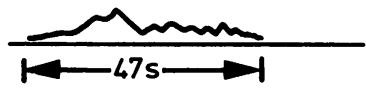

(b) Cystometry (CO 2 gas)

\begin{tabular}{|l|c|}
\hline Volume & $84 \mathrm{ml}$ \\
\hline Peak flow rate & $6.1 \mathrm{ml} / \mathrm{s}$ \\
\hline Micturition time & $47 \mathrm{~s}$ \\
\hline Residual urine volume & $45 \mathrm{ml}$ \\
\hline
\end{tabular}

\begin{tabular}{|c|c|c|c|}
\hline & $\begin{array}{c}\text { Pressure } \\
\left(\mathrm{cm} \mathrm{H}_{2} \mathrm{O}\right)\end{array}$ & Volume $(\mathrm{ml})$ & $\begin{array}{c}\text { Compliance } \\
\left(\mathrm{ml}^{\prime} \mathrm{cm} \mathrm{H}_{2} \mathrm{O}\right)\end{array}$ \\
\hline 0 & 4 & 20 & 99.9 \\
1 & 8 & 84 & 8.4 \\
2 & 9 & 131 & 22.2 \\
3 & 46 & 126 & 2.6 \\
\hline
\end{tabular}

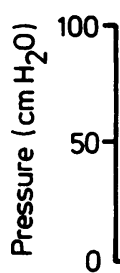

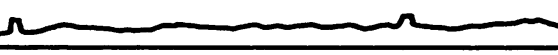

Time

Fig: Urodynamic tests. The data showed extension of micturition time and high urethral pressure. Abbreviations; FDV: First desire to void, MDV: Maximal desire to void, UPP: Urethral pressure profile. 
urethral pressure was high $\left(94 \mathrm{~cm} \mathrm{H}_{2} \mathrm{O}\right)$ in the urethral pressure profile.

\section{Discussion}

More than 20 cases of so-called pure dysautonomia have been reported..$^{1-9}$ Some of these patients ${ }^{13-5}$ had abnormalities in both the cholinergic and noradrenergic autonomic systems and therefore constitute a separate group that will be referred to as the "panautonomic dysfunction" group. In all these patients, orthostatic hypotension was a prominent symptom. The other patients ${ }^{2-9}$ showed only cholinergic autonomic dysfunction without any noradrenergic abnormality and therefore constitute a separate "cholinergic autonomic dysfunction" group.

Our patient showed various signs and symptoms of acute paralysis of 'mainly parasympathetic functions without evidence of other clinical and neurological abnormalities. The symptoms and clinical course observed in this case were similar to those of patients with acute pandysautonomia..$^{1-9}$ The prominent feature of this case was the parasympathetic failure that was reflected in impaired lachrymation and salivation, loss of pupillary constriction, decreased gastrointestinal motility, and atony of the bladder. Pharmacological testing demonstrated supersensitivity of the pupils to pilocarpine. Sweating was markedly diminished in response to body heating. The sweat glands, though innervated by the sympathetic nervous, are cholinergic. The coefficient of variation of the R-R interval in the ECG showed that the cholinergic autonomic system of the heart was normal, and the pupillary responses and vascular reflexes showed that the adrenergic autonomic systems were almost normal. Judging from the results of urinary flow measurements and cystometry, the atony of the bladder was produced by the adrenergic system, but may be due to supranuclear damage as indicated by the high urethral pressure in the urethral pressure profile. Several disorders affecting the peripheral nervous roots cause autonomic dysfunction. These include, among others, diabetes mellitus, amyloidosis, and tabes dorsalis, all of which have been excluded in this case by the clinical history and laboratory data. Therefore, this is a case of "cholinergic autonomic dysfunction" in pure dysautonomia.

The patient was treated by the administration of prednisolone $(20 \mathrm{mg} /$ day $)$. Although the effect of prednisolone was not clear, eventually she made a slow and partial spontaneous recovery: near visual acuity was increased, reaction to light and accommodation of the pupils became sluggish, tonic pupil (light-near dissociation) was observed, and sweating function improved.

The pathogenesis of pure dysautonomia is not clear, but the clinical features, together with the documented recovery of function and regeneration of unmyelinated fibres are consistent with an immunological basis of the disorder. ${ }^{3}$ Supporting evidence for an autoimmune mechanism behind pure dysautonomia is derived from the work of Appenzeller et al, ${ }^{10}$ who experimentally induced autonomic neuropathy in rabbits by the injection of homogenates of human sympathetic ganglia with Freund's adjuvant. The animal disease was transient and was associated with circulating antibodies to a sympathetic tissue antigen. Pathological examination of animals with experimental autonomic neuropathy showed perivascular lymphocytic infiltrates in sympathetic ganglia.

We could not diagnose this case as Sjögren's syndrome because of negative light microscopic finding of the salivary gland, in spite of positive anti SS-A antibody, the diffuse pattern of antinuclear antibodies and low titre of serum complement. Two histopathological types of inflammatory vascular disease (IVD) occurring in Sjögren's syndrome: neutrophilic IVD and mononuclear IVD. IVD has been significantly associated with seroreactivity reflected by anti SS-A antibody, antinuclear antibodies, rheumatoid factor and hyperglobulinaemia ${ }^{11} \mathrm{~A}$ possible relationship between nervous system disease and peripheral IVD in Sjögren's syndrome has been suggested by several investigators. ${ }^{12-14}$ Patients with either histopathologic type of IVD are at risk for the development of nervous system abnormalities. Indirect evidence suggests that IVD plays a role in the immunopathogenesis of nervous system disease. Unfortunately, confirmation by histological study (sural nerve biopsy) could not be done, because permission for the procedure was refused. Patients with CNS disease that cannot be attributed to a particular aetiology, should be carefully evaluated for Sjögren's syndrome and the presence of IVD. ${ }^{15}$ The presence of anti SS-A antibody in this patient suggests that this disorder was caused by an immune mechanism.

\section{References}

1 Young RR, Asbury AK, Adams RD, Corbett JL, et al. Pure pan-dysautonomia with recovery. Trans Am Neurol Assoc 1969;94:355-7.

2 Thomashefsky AJ, Horwitz SJ, Feingold MH. Acute autonomic neuropathy. Neurology 1972;22:251-55.

3 Appenzeller O, Kornfeld M. Acute pandysautonomia, clinical and morphologic study. Arch Neurol 1973;29:334-9.

4 Yahr MD, Frontera AT. Acute autonomic neuropathy, its occurrence in infectious mononucleosis. Arch Neurol 1975;32:132-3.

5 Okada F, Yamashita I, Suwa N. Two cases of acute pandysautonomia. Arch Neurol 1975;32:146-51. 
6 Colan RV, Snead OC, Oh SJ, et al. Acute autonomic and sensory neuropathy. Ann Neurol 1980;8:441-4.

7 Andersen O, Lindberg J, Modigh K, et al. Subacute dysautonomia with incomplete recovery. Acta Neurol Scand 1972;48:510-9.

8 Hopkins A, Neville B, Bannister R. Autonomic neuropathy of acute onset. Lancet 1974;1:769-71.

9 Harik SI, Ghandour MH, Farah FS, et al. Postganglionic cholinergic dysautonomia. Ann Neurol 1977;1:393-6.

10 Appenzeller O, Arnason BG, Adams RD. Experimental autonomic neuropathy: an immunologically induced disorder of reflex vasomotor function. $J$ Neurol Neurosurg Psychiatry 1965;28:510-5.

11 Molina R, Provost TT, Alexander EL. Two types of inflammatory vascular disease in Sjögren's syndrome. Arthritis Rheum 1985;28:1251-8.

12 Kaltreider HB, Talal N. The neuropathy of Sjögren's syndrome: trigeminal nerve involvement. Ann Intern Med 1969;70:751-62.

13 Alexander EL, Craft C, Dorsch C, et al. Necrotizing arteritis and spinal subarachnoid haemorrhage in Sjögren's syndrome. Ann Neurol 1982;11:632-5.

14 Steinberg AD, Green WT, Talal N. Thrombotic thrombocytopenic purpura complicating Sjögren's syndrome. JAMA 1971;215:757-61.

15 Molina R, Provost TT, Alexander EL. Peripheral inflammatory vascular disease in Sjògren's syndrome. Arthritis Rheum 1985;28:1341-7. 